\title{
Congenital heart disease in Ceylon
}

\author{
N. J. Wallooppillai and M. de S. Jayasinghe \\ From Cardiac Investigation Unit, General Hospital, Colombo, Ceylon
}

An analysis of 555 consecutive cases of congenital heart disease in Ceylon has shown that for the whole series interatrial septal defect is the commonest cardiac lesion; next is interventricular septal defect, followed by persistent ductus arteriosus. Interventricular and interatrial septal defects are equally common among all the patients below I6 years of age, but interventricular septal defects are commonest among those below II years. Persistent truncus arteriosus is unusually common, while coarctation of the aorta and congenital aortic stenosis are rare, as compared with series reported from other places.

Numerous studies of the pattern and the incidence of congenital heart disease have been reported from the West. But in SouthEast Asia congenital heart disease has not been studied adequately.

This work is an analysis of 555 cases of congenital heart disease, in which the pattern of the individual lesions and the age distribution are defined. A similar study has not been previously reported from Ceylon.

\section{Subjects and methods}

A prospective study of congenital heart disease was begun at the Cardiac Investigation Unit, General Hospital, Colombo, in May 1967 and was completed in July I969. The total number of consecutive cases studied was 555. Right and left cardiac catheterization studies and selective angiography were done on 496 patients; 57 straightforward cases of persistent ductus arteriosus, where the right ventricular pressure clinically was estimated to be near normal, were not subjected to catheterization, but the diagnoses were confirmed at subsequent operation. In addition, there were 2 cases of complete transposition of the great arteries diagnosed by routine investigations, and confirmed at operation.

\section{Findings}

The relative incidence and the age distribution of the various congenital cardiac malformations in the 555 cases are shown in Table I. The age and sex distributions for the commoner lesions are given in Table 2 .

Interatrial septal defect was the commonest malformation and occurred in 174 patients (3I.9\%); of these, I70 patients had ostium secundum defects and only 4 patients had ostium primum defects. The patients with ostium primum defects were children (pub-

Received 29 September 1969. erty taken as 15 years). Ninety-two of the patients with interatrial septal defects were adults (above 16 years), which accounts for 48.7 per cent of the adults with congenital heart disease. These findings agree with those of Kaplan (1968) that ostium secundum defects are the commonest cardiac malformations in the adult. The 82 children with interatrial septal defects constitute 22 per cent of the children with congenital heart disease. There were more women than men affected, the sex ratio being 5:3. Wood (I968) gives a female to male ratio of 3:2.

An interventricular septal defect was found in 99 patients $(17.6 \%), 82$ being children. Thus, interventricular septal defects were as common as interatrial septal defects among those below I5 years but they were much less common in the older age-groups (Table 2). Three of the patients with interventricular septal defects had congenital aortic incompetence in addition.

There were 93 patients in the series with persistent ductus arteriosus $(14.8 \%) ; 75$ of these were children. It is thrice as common in female patients as in male patients. Gross (I952) gave a female to male ratio of $7: 3$, while Friedberg (1966) gave a female to male ratio of $3: 1$.

By contrast with the whole series, among the 259 patients below I I years of age, we found that interventricular septal defects were the commonest, constituting $7 \mathrm{r}$ patients $(26.9 \%)$. Persistent ductus arteriosus with 60 patients $(22.9 \%)$ came next, and interatrial septal defect with 38 patients $(14.3 \%)$ was the third most common lesion.

In the whole series pulmonary stenosis with intact interventricular and interatrial septa and normal aortic root was fourth in order of 
TABLE I Incidence and age distribution of different congenital cardiac lesions

\begin{tabular}{|c|c|c|c|c|c|c|c|c|c|c|c|c|c|}
\hline \multirow[t]{2}{*}{ Lesions } & \multicolumn{11}{|c|}{ No. of patients in different age-groups } & \multirow{2}{*}{$\begin{array}{c}\text { Total } \\
\text { no. }\end{array}$} & \multirow{2}{*}{$\begin{array}{l}\text { Per cent } \\
\text { of total } \\
\text { (555) }\end{array}$} \\
\hline & $\begin{array}{l}0-6 \\
\text { mth. }\end{array}$ & $\begin{array}{l}7-12 \\
\text { mth. }\end{array}$ & $\begin{array}{l}13 \text { mth. } \\
\text { to } 2 y r .\end{array}$ & $\begin{array}{l}3-5 \\
y r .\end{array}$ & $\begin{array}{l}6-10 \\
y r .\end{array}$ & $\begin{array}{l}I I-15 \\
y r .\end{array}$ & $\begin{array}{l}16-20 \\
y r .\end{array}$ & $\begin{array}{l}21-30 \\
y r .\end{array}$ & $\begin{array}{l}31-40 \\
y r .\end{array}$ & $\begin{array}{l}41-50 \\
y r .\end{array}$ & $\begin{array}{l}5 I-60 \\
y r .\end{array}$ & & \\
\hline $\begin{array}{l}\text { Atrial septal } \\
\text { defect } \\
\text { Ventricular }\end{array}$ & 2 & I & I & 12 & 22 & 44 & 3I & 35 & 18 & 6 & 2 & I74 & $31 \cdot 9$ \\
\hline $\begin{array}{c}\text { septal defect } \\
\text { Persistent ductus }\end{array}$ & s 6 & 4 & 19 & 18 & 24 & II & 8 & 7 & 2 & - & - & 99 & $17 \cdot 6$ \\
\hline $\begin{array}{l}\text { arteriosus } \\
\text { Pulmonary }\end{array}$ & - & 3 & 13 & 21 & 23 & 15 & 8 & 7 & 2 & I & - & 93 & 14.8 \\
\hline $\begin{array}{l}\text { stenosis } \\
\text { Fallot's }\end{array}$ & - & 2 & I & 5 & 13 & 13 & II & 17 & 6 & I & I & 70 & 12.6 \\
\hline $\begin{array}{l}\text { tetralogy } \\
\text { Truncus }\end{array}$ & I & I & 4 & 4 & 10 & IO & 10 & I & - & - & - & 4I & $7 \cdot 5$ \\
\hline $\begin{array}{l}\text { arteriosus } \\
\text { Pulmonary } \\
\text { stenosis with } \\
\text { atrial or } \\
\text { ventricular }\end{array}$ & 3 & 2 & 7 & 6 & 4 & 7 & I & I & I & - & - & 32 & 5.9 \\
\hline $\begin{array}{l}\text { septal defect } \\
\text { Dextrocardia } \\
\text { with com- } \\
\text { bined }\end{array}$ & - & - & - & 3 & ro & 4 & 3 & 3 & 2 & - & - & 25 & $4 \cdot 6$ \\
\hline $\begin{array}{l}\text { anomalies } \\
\text { Coarctation }\end{array}$ & - & - & I & 2 & 4 & I & I & - & - & - & - & 9 & $1 \cdot 6$ \\
\hline $\begin{array}{l}\text { of aorta } \\
\text { Ebstein's }\end{array}$ & - & - & - & - & I & I & - & I & I & - & - & 4 & 0.7 \\
\hline $\begin{array}{l}\text { anomaly } \\
\text { Tricuspid }\end{array}$ & - & - & I & - & - & I & I & - & - & - & - & 3 & 0.5 \\
\hline $\begin{array}{l}\text { atresia } \\
\text { Complete }\end{array}$ & - & - & I & 2 & - & - & - & - & - & - & - & 3 & 0.5 \\
\hline transposition & 2 & 一 & - & - & - & 一 & - & - & - & - & - & 2 & 0.4 \\
\hline All lesions & 14 & 13 & 48 & 73 & III & 107 & 74 & 72 & 32 & 8 & 3 & 555 & \\
\hline
\end{tabular}

frequency, accounting for 70 patients ( $12 \cdot 6 \%$ ). Forty-five of these patients had valvular pulmonary stenosis, 20 had infundibular stenosis, and 5 had combined valvular and infundi- bular stenosis. There were more affected male patients than female patients, with a male to female sex ratio of $2: I$.

Fifth in descending order of frequency was

TABLE 2 Age and sex distribution in commoner congenital cardiac lesions

\begin{tabular}{|c|c|c|c|c|c|c|c|c|c|c|c|c|c|c|}
\hline \multirow[t]{2}{*}{ Age } & \multicolumn{2}{|c|}{$\begin{array}{l}\text { Atrial } \\
\text { septal } \\
\text { defect }\end{array}$} & \multicolumn{2}{|c|}{$\begin{array}{c}\text { Ventricular } \\
\text { septal } \\
\text { defect }\end{array}$} & \multicolumn{2}{|c|}{$\begin{array}{c}\text { Persistent } \\
\text { ductus } \\
\text { arteriosus }\end{array}$} & \multicolumn{2}{|c|}{$\begin{array}{c}\text { Pulmonary } \\
\text { stenosis }\end{array}$} & \multicolumn{2}{|c|}{$\begin{array}{c}\text { Fallot's } \\
\text { tetralogy }\end{array}$} & \multicolumn{2}{|c|}{$\begin{array}{c}\text { Truncus } \\
\text { arteriosus }\end{array}$} & \multicolumn{2}{|c|}{$\begin{array}{c}\text { Pulmonary } \\
\text { stenosis } \\
\text { with } \\
A S D / V S D\end{array}$} \\
\hline & $F$ & $M$ & $F$ & $M$ & $\boldsymbol{F}$ & $M$ & $\boldsymbol{F}$ & $M$ & $F$ & $M$ & $F$ & $M$ & $F$ & $M$ \\
\hline $0-6 \mathrm{mth}$. & 2 & - & 4 & 2 & - & - & - & - & - & $\mathbf{I}$ & 2 & I & - & - \\
\hline yr. & - & $\mathbf{I}$ & 9 & I0 & II & 2 & 一 & - & $\mathbf{I}$ & 3 & $\mathbf{I}$ & 6 & - & - \\
\hline $3-5$ yr. & 7 & 5 & 9 & 9 & I4 & 7 & $\mathbf{I}$ & 5 & 2 & 2 & 4 & 2 & $\mathbf{I}$ & 2 \\
\hline 6-ro yr. & I4 & 8 & 12 & 12 & 18 & 5 & 4 & 9 & 4 & 6 & 2 & 2 & 6 & 4 \\
\hline I I-I 5 yr. & 32 & 12 & 6 & 5 & II & 4 & 5 & 8 & 5 & 5 & - & 7 & $\mathbf{I}$ & 3 \\
\hline I6-20 yr. & 19 & 12 & 3 & 5 & 6 & 2 & 2 & 9 & 7 & 3 & - & I & $\mathbf{I}$ & 2 \\
\hline $5 \mathrm{I}-60 \mathrm{yr}$ & - & 2 & - & - & - & - & - & $\mathbf{I}$ & - & - & - & - & - & - \\
\hline Total & 109 & 65 & 49 & 50 & 70 & 23 & 24 & 46 & 20 & 21 & 12 & 20 & 12 & I3 \\
\hline
\end{tabular}


Fallot's tetralogy which was found in 4I patients $(7.5 \%)$. This lesion was equally distributed between the sexes.

Persistent truncus arteriosus was the sixth commonest cardiac malformation, with 32 patients $(5.9 \%)$. Fontana and Edwards (1962) found an incidence of 2.3 per cent of truncus arteriosus in a pathological study of congenital hearts. Truncus arteriosus is nearly twice as common in male patients as in female patients. Bruins and Dekker (1968) recorded similar findings.

Pulmonary stenosis with interatrial or interventricular septal defect and a normal aortic root was found in 25 patients $(4.6 \%)$. Unlike the group with isolated pulmonary stenosis, there was no sex difference in this group.

\section{Comment}

This study does not give the incidence of congenital heart disease in the total population, as it was confined to hospital admissions, and it also excludes cases of severe cardiac malformation dying in early infancy. The relative incidence of the various abnormalities found in this series is compared with those in some other reported series in Table 3.

Interatrial septal defect is the commonest congenital malformation seen in Ceylon; interventricular septal defect is the commonest congenital malformation seen in the West. It is interesting to note that of the total number of patients catheterized during this period, 9.6 per cent had probe patency of the foramen ovale. When patients with an atrial septal defect are excluded this increases to 10.6 per cent.

The fall in the incidence of ventricular septal defect as the age-group changes from under II years to adolescence and adulthood (Table I) deserves mention. We do not know whether this is because spontaneous closure of the ventricular septal defect occurs or whether some of them die before reaching adulthood. Follow-up of our cases should give the answer.

Coarctation of the aorta is rare among the Ceylonese $(0.8 \%)$ in this series. We have not come across any cases of congenital aortic stenosis. Both these lesions are relatively common in Western countries.

The incidence of pulmonary stenosis is similar to that seen in Western countries (Nadas, 1963; Wood, I968; Kjellberg et al., 1959), but this is double the incidence seen in the Far East (Wada, 1963; Shann, 1969).
TABLE 3 Incidence of congenital heart diseases reported from various countries

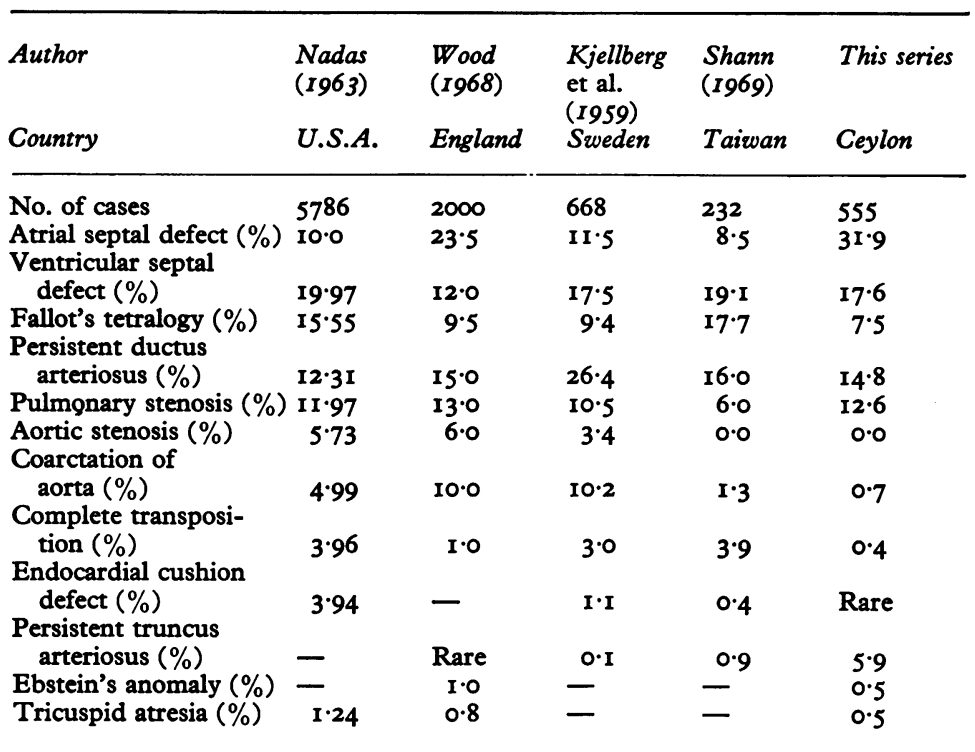

For some unaccountable reason persistent truncus arteriosus appears to be unusually common in Ceylon. We have not found such a high incidence reported elsewhere.

Our sincere thanks are due to Dr. M. Weerasena, radiologist, for the help in many facets of this work and to the physicians and surgeons referring patients, and to the staff of the Unit.

\section{References}

Bruins, C., and Dekker, A. (1968). Truncus arteriosus. In Paediatric Cardiology, p. 656. Ed. by H. Watson. Lloyd-Luke, London.

Fontana, R. S., and Edwards, J. E. (1962). Congenital Cardiac Disease; A Review of 357 Cases Studied Pathologically. Saunders, Philadelphia and London.

Friedberg, C. K. (1966). Diseases of the Heart, 3rd ed., p. 1260. Saunders, Philadelphia and London.

Gross, R. E. (1952). The patent ductus arteriosus. Observations on diagnosis and therapy in 525 surgically treated cases. American fournal of Medicine, 12, 472.

Kaplan, S. (1968). Atrial septal defects. In Paediatric Cardiology, p. 376. Ed. by H. Watson. LloydLuke, London.

Kjellberg, S. R., Mannheimer, E., Rudhe, U., and Jonsson, B. (1959). Diagnosis of Congenital Heart Disease, and ed. Year Book Publishers, Chicago.

Nadas, A. S. (1963). Pediatric Cardiology, 2nd ed. Saunders, Philadelphia and London.

Shann, M. K. M. (1969). Congenital heart disease in Taiwan, Republic of China. Circulation, 39, 251.

Wada, J. (1963). Congenital heart disease. Fapanese Circulation fournal (English ed.), 27, $25 \mathrm{I}$.

Wood, P. (1968). Diseases of the Heart and Circulation, 3rd ed. Eyre and Spottiswood, London. 